\title{
Hydroxyl, $\mathrm{Fe}^{2+}$, and Acidithiobacillus ferrooxidans Jointly Determined the Crystal Growth and Morphology of Schwertmannite in a Sulfate- Rich Acidic Environment
}

\author{
Kun Feng, Xiaomeng Wang, Bo Zhou, Min Xu, Jianru Liang, and Lixiang Zhou*
}

Cite This: ACS Omega 2021, 6, 3194-3201

Read Online

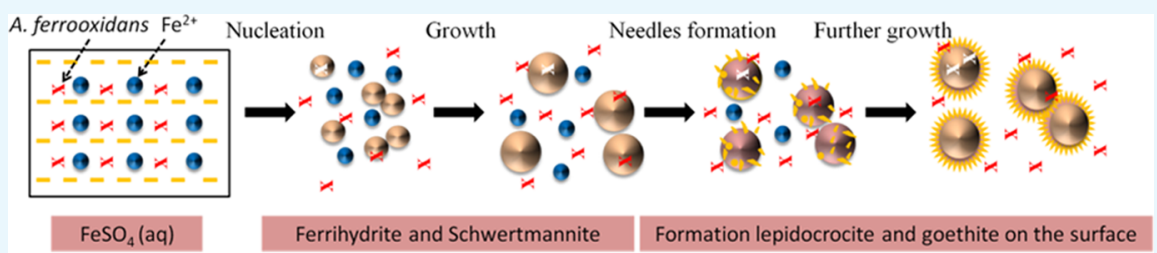

ABSTRACT: Schwertmannite, ubiquitously found in iron and sulfate-rich acid mine drainage, is generated via biological oxidation of ferrous ions by Acidithiobacillus ferrooxidans (A. ferrooxidans). However, little information on the mechanisms of biogenic schwertmannite formation and crystal growth is available. This study deliberately investigated the relationships among mineral morphology, solution chemistry, and phase transformation of schwertmannite in A. ferrooxidans-containing ferrous sulfate solutions. The formation of schwertmannite could be divided into three stages. In the first nucleation stage, crystallites are presented as nonaggregative or aggregative forms via a successive polymerization process. In the second stage, ellipsoidal aggregates, which are identified as ferrihydrite and/or schwertmannite, are formed. In the third stage, needles appear on the surface of ellipsoidal aggregates, which is caused by the phase transformation of ferrihydrite or schwertmannite to lepidocrocite and goethite through a $\mathrm{Fe}^{2+}$ (aq) catalysis-driven pathway. After three stages, a typical characteristic "hedgehog" morphology finally appears. In addition, $A$. ferrooxidans could significantly speed up the mineral transformation. Solution $\mathrm{pH}$ affects the morphology of schwertmannite by acid leaching. The experimental results also reveal that the formation of schwertmannite depend on the content of hydroxyl complexes or the transformation of the monomers to polymers, which are greatly affected by the solution $\mathrm{pH}$.

\section{INTRODUCTION}

Schwertmannite, a poorly ordered nanocrystalline ferric oxyhydroxysulfate mineral with a variable chemical formula $\mathrm{Fe}_{8} \mathrm{O}_{8}(\mathrm{OH})_{8-2 X}\left(\mathrm{SO}_{4}\right)_{X}(1 \leq X \leq 1.75)$, is widely distributed in sulfate-rich acid mine drainage (AMD) environments. ${ }^{1-3}$ Because of its high specific surface area, schwertmannite can serve as a potent adsorbent and repository for a variety of nutrients and toxic metals including phosphates, metalloids, and metal ions. ${ }^{2,4-7}$ In addition, schwertmannite is a bioavailable ferric oxyhydroxysulfate mineral prone to dissimilatory reduction by $\mathrm{Fe}(\mathrm{III})$-reducing microbes. Accordingly, its formation and phase transformation involves natural cycling of iron, carbon, phosphorus, and many other metal elements. ${ }^{5,8-10}$ Thus, understanding the formation mechanisms of schwertmannite mediated by bacteria is beneficial for clarifying biogeochemical cycling of $\mathrm{Fe}$ and developing novel environmental remediation materials.

In $\mathrm{AMD}$ environments, the abiotic oxidation of $\mathrm{Fe}^{2+}$ is greatly limited under low $\mathrm{pH}(<4.0)$ conditions. ${ }^{11}$ However, acidophilic $\mathrm{Fe}(\mathrm{II})$-oxidizing bacteria such as Acidithiobacillus ferrooxidans (A. ferrooxidans) accelerate the oxidation of $\mathrm{Fe}^{2+}$ $10^{5-6}$ time in an acidic environment. ${ }^{12}$ A. ferrooxidans, an acidophilic chemoautotrophic bacterium capable of oxidizing ferrous ions and elemental sulfur, is widely distributed in the AMD environment. ${ }^{13-15} \mathrm{Fe}^{2+}$ is firstly oxidized to $\mathrm{Fe}^{3+}$, subsequently the formed $\mathrm{Fe}^{3+}$ further coordinates with $\mathrm{SO}_{4}{ }^{2-}$ ions and $\mathrm{OH}^{-}$to generate schwertmannite in the AMD system. ${ }^{16-19}$ This process can be expressed by the following reactions

$$
\begin{aligned}
& 4 \mathrm{Fe}^{2+}+\mathrm{O}_{2}+4 \mathrm{H}^{+} \rightarrow 4 \mathrm{Fe}^{3+}+\mathrm{H}_{2} \mathrm{O} \\
& 8 \mathrm{Fe}^{3+}+x \mathrm{SO}_{4}^{2-}+(16-2 x) \mathrm{H}_{2} \mathrm{O} \\
& \quad \rightarrow \mathrm{Fe}_{8} \mathrm{O}_{8}(\mathrm{OH})_{8-2 x}\left(\mathrm{SO}_{4}\right)_{x}+(24-2 x) \mathrm{H}^{+}
\end{aligned}
$$

The resulting schwertmannite possesses a characteristic "hedgehog" morphology, which is composed of spherical nuclei of hundreds of nanometers in diameter and radialized needles. $^{1,20}$

Received: November 17, 2020

Accepted: January 11, 2021

Published: January 22, 2021 
(a)

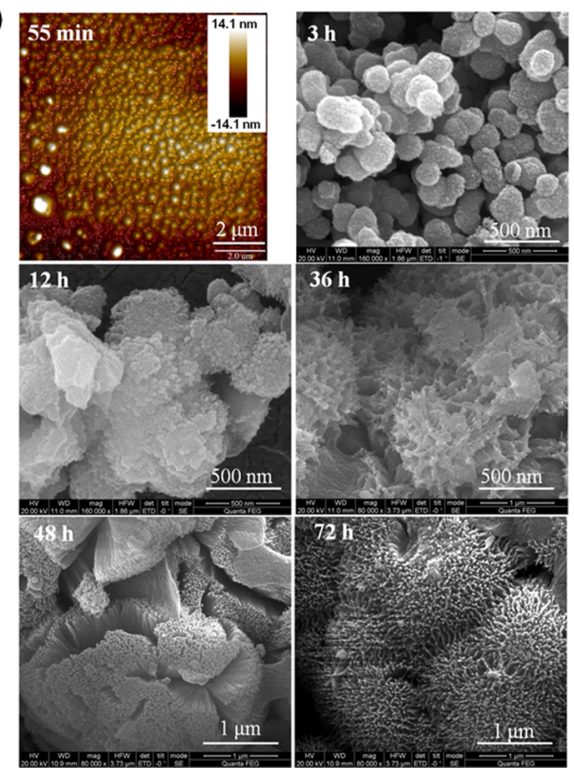

(b)

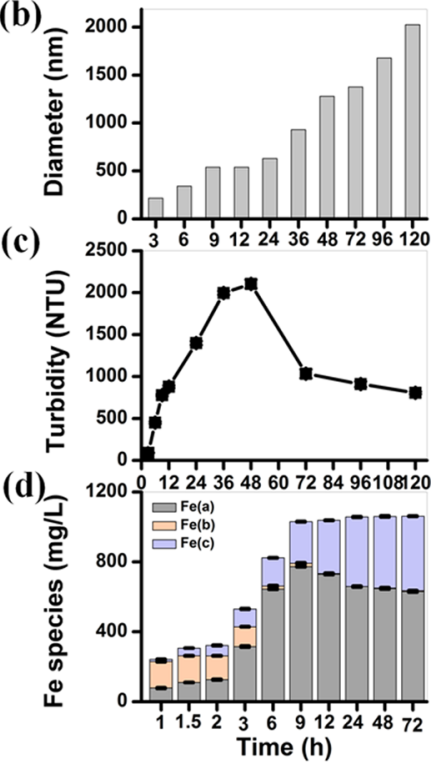

Figure 1. Changes of the particle morphology by AFM and scanning electron microscopy (SEM) (a), single ellipsoid diameter (b), solution turbidity $(\mathrm{c})$, and $\mathrm{Fe}$ species $(\mathrm{d})$ during the formation of schwertmannite driven by A. ferrooxidans in simulated AMD (A. ferrooxidans density: $6 \times$ $10^{7}$ cell $\mathrm{mL}^{-1}$; initial $\mathrm{pH}=2.5,80$ and $20 \mathrm{mM} \mathrm{FeSO}_{4}$ in $(\mathrm{a}-\mathrm{c})$ and (d), respectively).

Microorganisms and their extracellular polymeric substances (EPS) can adhere to nanoparticles and may influence the particle growth process, aggregation, and transformation. ${ }^{21}$ Fortin et al. found that the cells of $A$. ferrooxidans were encapsulated by jarosite-like minerals during the bacteriummediated mineral formation process. ${ }^{22}$ Similar results were also obtained by Ferris, who found that iron minerals were directly related to EPS, the cell wall, the periplasm, and the cytoplasmic membrane. ${ }^{23}$ However, the encrustation phenomenon on the cell surface was not observed during the Ferrovum myxofaciensmediated mineralization process. ${ }^{24}$ Liao et al. demonstrated that schwertmannite could be formed by $A$. ferrooxidans in $\mathrm{FeSO}_{4}$ solution at $\mathrm{pH} 1.6-3.5$. $^{20}$ Song et al. found that the morphology of schwertmannite would change if regulated by A. ferrooxidans with EPS stripping. ${ }^{7}$ In addition, for the $\mathrm{H}_{2} \mathrm{O}_{2}$ mediated schwertmannite synthesis, the morphology exhibited nanoparticle aggregated particle or characteristic hedgehog structure, depending on $\mathrm{H}_{2} \mathrm{O}_{2}$ supply rate. ${ }^{2,6}$ Even though the mineral morphology of biogenic schwertmannite mediated by A. ferrooxidans has been well characterized, the specific formation and crystal growth pathway still remain unknown.

Therefore, the objectives of this study were (i) to investigate the evolution process of morphology and corresponding solution chemistry during the biological synthesis process of schwertmannite; (ii) to identify the mineral phases in different growth stages; and (iii) to explore the key factors affecting schwertmannite formation. The findings will shed light on the development of more comprehensive models for nanoparticle formation, crystal growth, and phase transformation of schwertmannite. More significantly, it will clearly elucidate the role of microorganisms in the formation of biogenic schwertmannite.

\section{RESULTS AND DISCUSSION}

2.1. Identification of Crystal Growth, Particle Morphology, and Solution Chemistry in the Nucleation Stage. The formation of schwertmannite driven by $A$. ferrooxidans in simulated AMD during the initial $3 \mathrm{~h}$ was observed by atomic force microscopy (AFM) (Figures 1a, S2). The particles were smaller than $4 \mathrm{~nm}$ in height in the first 40 min, and were similar to those in $\mathrm{FeSO}_{4}$ solution dropped on quartz slides as control (Figure S2). The formed precipitates at $55 \mathrm{~min}$ were nonaggregative or aggregative crystallites with sizes below $26 \mathrm{~nm}$ (Figure 1a). Similarly, this phenomenon was also observed by cryo-transmission electron microscopy (TEM) during the nucleation stage of iron(III) oxide. $^{34}$ Subsequently, the particle size progressively increased as the reaction time increased (Figures 1b, S2).

Ferron assays were performed to identify the forms of existence of ferric ions, and quantify the concentration variation of $\mathrm{Fe}(\mathrm{a}), \mathrm{Fe}(\mathrm{b})$, and $\mathrm{Fe}(\mathrm{c})$ over the reaction time. $\mathrm{Fe}(\mathrm{a})$ referred to $\mathrm{Fe}$ monomers, such as $\mathrm{Fe}(\mathrm{OH})_{2}\left(\mathrm{H}_{2} \mathrm{O}\right)_{4}^{+}$, $\mathrm{Fe}(\mathrm{OH})_{2}{ }^{+}$, and $\mathrm{FeSO}_{4}{ }^{+}$, and $\mathrm{Fe}(\mathrm{b})$ referred to $\mathrm{Fe}$ polymers, like $\left[\mathrm{Fe}_{2}(-\mathrm{OH})_{5}\left(\mathrm{OH}_{2}\right)_{5}\right]^{0}{ }^{33} \mathrm{Fe}(\mathrm{c})$ was considered as the $\mathrm{Fe}$ species that could not react with the ferron reagent, namely stable precipitation. As shown in Figure 1d, the concentration of $\mathrm{Fe}(\mathrm{a})$ and $\mathrm{Fe}(\mathrm{c})$ gradually increased within $3 \mathrm{~h}$, whereas $\mathrm{Fe}(\mathrm{b})$ exhibited an opposite tendency. The previous report demonstrated that $\mathrm{Fe}$ oxide was formed via a successive polymerization process. ${ }^{35}$ Hydrolyzed Fe monomers possessed strong hydrolysis capacity and were hydrolyzed to form oligomers, such as dimers and trimers. Then these oligomers polymerized to form nuclei, which then organized into particles. $^{33,35-38}$ For example, Zhu et al. explored the formation pathways of ferrihydrite in acidic solution, and found that $\mathrm{Fe}$ existed mainly as $\mathrm{Fe}\left(\mathrm{H}_{2} \mathrm{O}\right)_{6}{ }^{3+}$ ( $\left.\mathrm{Fe}(\mathrm{a})\right), \mu$-oxo aquo dimers $(\mathrm{Fe}(\mathrm{b}))$ and ferrihydrite $(\mathrm{Fe}(\mathrm{c}))$ forms. ${ }^{35}$ The formed sulfate-complexed ferrihydrite-like molecular clusters were stable when the simulated AMD was neutralized with $\mathrm{NaHCO}_{3}\left(\left[\mathrm{HCO}_{3}{ }^{-}\right] /\left[\mathrm{Fe}^{3+}\right]=0.5\right.$ and 0.6$) .^{21}$ When the $\left[\mathrm{HCO}_{3}{ }^{-}\right] /\left[\mathrm{Fe}^{3+}\right]$ ratio was increased to 1.0 , a ferrhydrite-like molecular cluster was formed initially but subsequently converted to schwertmannite. For the biological synthesis of schwertmannite, the conversion from $\mathrm{Fe}^{3+}$ monomers to oligomers was the first key step, and ferrihydrite might be the main crystallite formed in $55 \mathrm{~min}$. 
Solution turbidity used to monitor the crystallization process displayed a steady state during the first $150 \mathrm{~min}$, and then sharply increased to the maximum value of $2250 \mathrm{NTU}$ in $48 \mathrm{~h}$ (Figure 1c). This phenomenon was consistent with the morphology change presented in AFM images, which indicated that the crystallite continuously grew into a number of particles. Correspondingly, the solution $\mathrm{pH}$ increased from 2.5 to 2.8 within $3 \mathrm{~h}$ (Figure 2a), which is ascribed to the
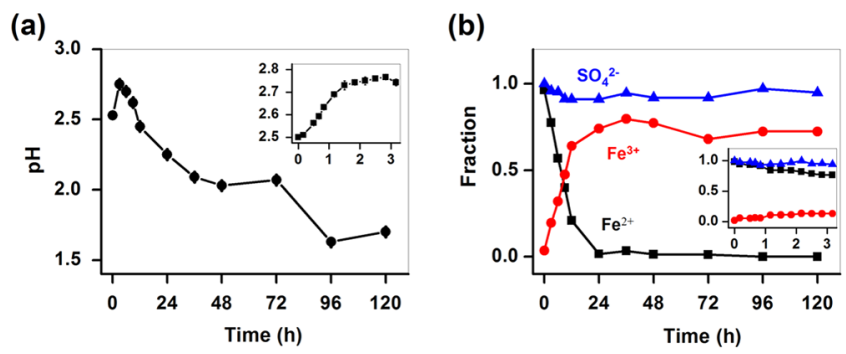

Figure 2. Changes of solution $\mathrm{pH}(\mathrm{a})$ and dissolved ion $\left(\mathrm{Fe}^{2+}, \mathrm{Fe}^{3+}\right.$ and $\mathrm{SO}_{4}{ }^{2-}$ ) fraction (b) during the formation of schwertmannite driven by $A$. ferrooxidans in simulated AMD. The inset demonstrates the solution chemistry in the first $3 \mathrm{~h}$. Experimental conditions: 80 $\mathrm{mM} \mathrm{FeSO}_{4}$; A. ferrooxidans density: $6 \times 10^{7}$ cell $\mathrm{mL}^{-1}$; initial $\mathrm{pH}=$ 2.5.

consumption of protons caused by oxidization of ferrous ion to ferric ion (Reaction 1). Previous works conducted by Liao et al. showed that a rising trend of $\mathrm{pH}$ of the solution was observed during the early stage of the reaction when the initial $\mathrm{pH}$ of the solution was as low as 2.6 or below. ${ }^{20}$ The $\mathrm{Fe}^{2+}$ concentration drastically decreased from 98.4 to $76.7 \%$ in this stage, while resultant $\mathrm{Fe}^{3+}$ exhibited an opposite trend increasing from 1.65 to $13 \%$ (Figure $2 \mathrm{~b}$ ). This indicated that the generation efficiency of $\mathrm{Fe}^{3+}$ from bio-oxidation of $\mathrm{Fe}^{2+}$ was much higher than that by the hydrolysis of ferric ions in this stage.

2.2. Evolution of Particle Morphology and Phase Identification of Ellipsoidal Aggregates. Schwertmannite further grew into compact ellipsoidal aggregates of about 217.4-600.6 $\mathrm{nm}$ in size with a relatively smooth structure during the reaction from 3 to $12 \mathrm{~h}$ (Figure $1 \mathrm{a}, \mathrm{b}$ ). The morphology of these ellipsoidal aggregates was consistent with that of chemosynthetic schwertmannite formed by adding $\mathrm{H}_{2} \mathrm{O}_{2}$ at one time. ${ }^{2}$ The solution turbidity correspondingly increased from 96.1 to $879 \mathrm{NTU}$, while solution $\mathrm{pH}$ decreased from 2.8 to 2.4. It showed that a $\mathrm{pH}$ increase caused by biooxidation of $\mathrm{Fe}^{2+}$ would be quickly counteracted by the proton release from the subsequent hydrolysis of $\mathrm{Fe}^{3+}$, which finally led to the decrease of solution $\mathrm{pH}$.

In addition, the mineral phase was identified by X-ray diffraction (XRD) analyses in Figure 3a. In the light of the patterns of ferrihydrite (PDF 29-0712) and schwertmannite (PDF 47-1775), the diffraction peaks and relative intensities of precipitate collected at $3 \mathrm{~h}$ agreed well with the standard ferrihydrite and schwertmannite, respectively. To further investigate the mineral species, the precipitate was analyzed via Mössbauer spectra at $77 \mathrm{~K}$ in Figure $3 \mathrm{~b}$, which was identified as the mixture phase of 2-line ferrihydrite (67.6\%) and schwertmannite (32.4\%).

As shown in Table S1, the proportion of ferrihydrite decreased from 67.6 to $7.2 \%$ as the mineral grew from 3 to 120 $\mathrm{h}$, while the schwertmannite portion was increased from 32.4 to $38.5 \%$. This indicated that partial ferrihydrite was transformed into schwertmannite. A previous study also demonstrated that ferrihydrite particles formed during AMD neutralization by $\mathrm{NaHCO}_{3}$ could rapidly convert into schwertmannite. $^{21}$ They also proposed that schwertmannite could be directly formed by the dissolved $\mathrm{Fe}$ species, indicating that ferrihydrite was not an indispensable precursor for its formation. Since the Gibbs free energy for the formation of ferrihydrite $\left(\Delta_{r} G^{0}=-469.9 \pm 1.4 \mathrm{~kJ} \mathrm{~mol}^{-1}\right)$ was much lower than that of schwertmannite $\left(\Delta_{r} G^{0}=-34.12 \mathrm{~kJ} \mathrm{~mol}^{-1}\right),{ }^{28,39,40}$ ferrihydrite was preferably formed in the initial stage because of the lower nucleation energy barrier.

2.3. Formation of the Hedgehog Morphology via Mineral Phase Transformation. Along with the prolonged reaction time of $12 \mathrm{~h}$, some readily observed bulges appeared on the surface of ellipsoidal aggregates (Figures 1a, S3). Furthermore, TEM images of mineral collected at $36 \mathrm{~h}$ and $120 \mathrm{~h}$ indicated that the bulges evolved into needles radiating from the surface of ellipsoidal aggregates (Figure S4), while the average diameter of ellipsoid increased gradually from 929.9 to $2024 \mathrm{~nm}$ within $84 \mathrm{~h}$ (Figure $1 \mathrm{~b}$ ). These images clearly proved that needles formed and grew on the surface of ellipsoidal aggregates instead of growing from a small central nucleus. Notably, the typical hedgehog morphology of schwertmannite was well developed after $48 \mathrm{~h}$ with needles surrounding the aggregates (Figure 1a).

This trend was well coincident with the turbidity evolution plotted against the reaction time. The turbidity continuously decreased after $48 \mathrm{~h}$, which might be attributed to the phase transformation. ${ }^{1}$ To illustrate this point, HRTEM was performed to observe the high-resolution images of bulges on the surface of ellipsoidal aggregates collected at $36 \mathrm{~h}$. Lattice fringes with an average spacing of 3.31 and $2.57 \AA$ were (a)

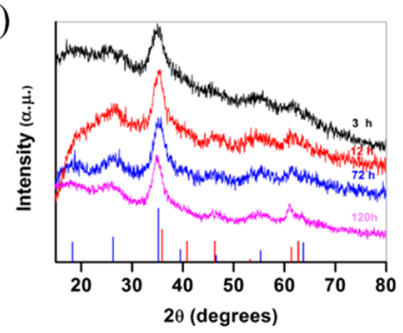

(b)

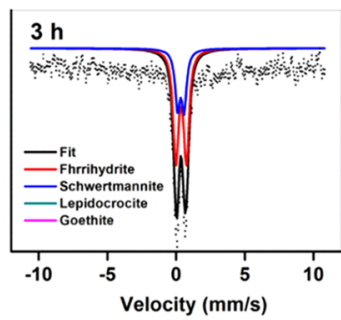

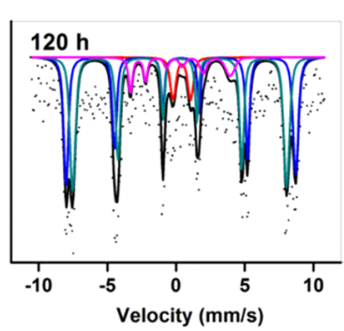

Figure 3. (a) XRD patterns of the mineral formed after 3, 12, 72, and $120 \mathrm{~h}$. The red and blue lines represent the standard ferrihydrtie XRD patterns (JCPD: 29-0712) and schwertmannite XRD patterns (JCPD: 47-1775) at the bottom of the figure. (b) Fitted Mössbauer spectra recorded at $77 \mathrm{~K}$ for minerals obtained after 3 and $120 \mathrm{~h}$. The spectral fitting parameters are shown in Table S1. Experimental conditions: $80 \mathrm{mM} \mathrm{FeSO}$; $A$. ferrooxidans density $6 \times 10^{7}$ cell $\mathrm{mL}^{-1}$; initial $\mathrm{pH}=2.5$. 

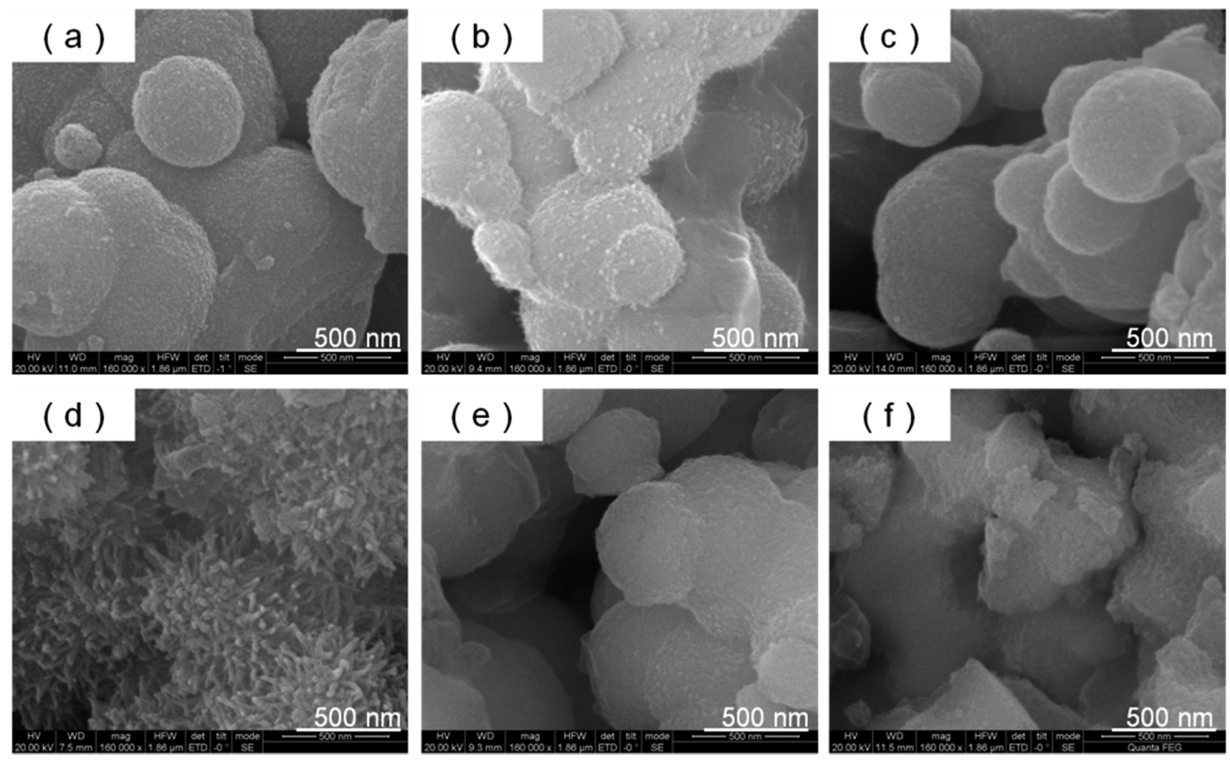

Figure 4. SEM images showing the morphology of $9 \mathrm{~h}$ mineral (pristine mineral) (a), when they were immersed in $30 \mathrm{mM} \mathrm{FeSO}_{4}$ solution $(\mathrm{pH}=$ 2.6) (b); inactive A. ferrooxidans suspension ( $\mathrm{pH}=2.6)(\mathrm{c}) ; 30 \mathrm{mM} \mathrm{FeSO}_{4}$ solution with inactive A. ferrooxidans suspension $(\mathrm{pH}=2.6)(\mathrm{d})$; aqueous solution with $\mathrm{pH}=2.6(\mathrm{e})$ and aqueous solution with $\mathrm{pH}=2.0(\mathrm{f})$, respectively.

clearly observed, which were closely matched the spacing of the [003] and [021] planes in ferrihydrite and goethite, respectively (Figure S5). Hockridge et al. also reported that the aggregates formed in the early stages of chemosynthetic schwertmannite composed of nanometer-scaled ferrihydrite crystallites, whereas mature needles on the surface of ellipsoidal aggregates were made up of goethite nanoparticles. ${ }^{1}$ Moreover, Mössbauer analysis of the $120 \mathrm{~h}$ sample showed (Figure $3 \mathrm{~b}$ ) that the mineral components were identified as ferrihydrite (7.2\%), schwertmannite (38.5\%), lepidocrocite (45\%), and goethite (9.3\%). Compared with the ellipsoidal aggregates with a relatively smooth surface, the needles on the surface of ellipsoidal aggregates were lepidocrocite and goethite.

Meanwhile, as shown in Figure 2b, the fraction of $\mathrm{Fe}^{2+}$ decreased and reached nearly zero after $48 \mathrm{~h}$. However, the fraction of $\mathrm{Fe}^{3+}$ exhibited an opposite trend, in which the percentage of $\mathrm{Fe}^{3+}$ gradually increased in this stage and stabilized at approximately $72.7 \%$ after $48 \mathrm{~h}$. In addition, $\mathrm{SO}_{4}{ }^{2-}$ gradually decreased to $90 \%$ after $48 \mathrm{~h}$ and remained constant afterward. Obviously, these results indicated that the $\mathrm{Fe}^{2+}$ biooxidation had been terminated after $48 \mathrm{~h}$, and the resultant $\mathrm{Fe}^{3+}$ was not completely transformed into schwertmannite. Correspondingly, only $28 \%$ of iron and $10 \%$ of sulfate were incorporated into the precipitate after $120 \mathrm{~h}$ of the reaction. This result was in agreement with those reported by previous studies, in which total iron precipitation efficiency was stable at about $30 \%$ during schwertmannite formation by $A$. ferrooxidans oxidation. ${ }^{11,28}$ However, solution $\mathrm{pH}$ still gradually decreased after $48 \mathrm{~h}$ (Figure 2a) due to the hydrolysis of resultant $\mathrm{Fe}^{3+}$, which would be discussed further later.

2.4. Effects of Solution Chemistry on Mineral Morphology. The mineral obtained at $9 \mathrm{~h}$ was used to explore the formation process of needles on the surface of ellipsoidal aggregates in different solution chemistry. Compared with the pristine mineral (Figure 4a), the already-formed mineral sample immersed in $30 \mathrm{mM} \mathrm{FeSO}_{4}$ solution for $108 \mathrm{~h}$ $(\mathrm{pH}=2.6)$ exhibited a small number of needles growing on the surface of ellipsoidal aggregates (Figure $4 \mathrm{~b}$ ). On the contrary, no significant changes were observed for the samples immersed in aqueous solution at $\mathrm{pH}=2.6$ in the presence (Figure 4c) or absence (Figure 4e) of inactive A. ferrooxidans suspension. Moreover, the typical morphology of abundant needles radiating from the surface of ellipsoidal aggregates was observed when the mineral was immersed in $30 \mathrm{mM} \mathrm{FeSO}_{4}$ aqueous solution $(\mathrm{pH}=2.6)$ containing inactive $A$. ferrooxidans suspension (Figure $4 \mathrm{~d}$ ). The findings demonstrated that $\mathrm{Fe}^{2+}(\mathrm{aq})$ contributed to the formation of needles on the surface of ellipsoidal aggregates, and A. ferrooxidans accelerated this process. Many researchers also reported that ferrihydrite or schwertmannite could transform into lepidocrocite and goethite through a $\mathrm{Fe}^{2+}$ (aq) catalysis-driven pathway. ${ }^{41-44}$ It was also well documented that there was a long-range electron transfer pathway between the microbialmineral interface. It was just like hematite that could act as a conductor and accelerate electron directly from $\mathrm{Fe}^{2+}$ to cells. ${ }^{45}$ However, $\mathrm{Fe}^{2+}$ (aq) catalysis-driven formation of needles on the surface of schwertmannite in the presence of $A$. ferrooxidans cell still was not reported. Here, we speculated that some active substances generated from $A$. ferrooxidans cell could accelerate the electron transfer between $\mathrm{Fe}^{2+}$ and minerals. Further studies are needed to clarify the mechanism involved in mineral phase transformation driven by $\mathrm{Fe}^{2+}$ (aq) in the presence of $A$. ferrooxidans.

As shown in Figure $4 \mathrm{f}$, the mineral immersed in aqueous solutions with $\mathrm{pH}=2.0$ generated some hypoplastic ellipsoidal aggregates, indicating that the mineral was partially dissolved. The discrepancies of mineral morphology presented in Figures $4 \mathrm{e}, \mathrm{f}$ was due to the decline of solution $\mathrm{pH}$, which was caused by proton generation from the hydrolysis of $\mathrm{Fe}^{3+}$ and mineral phase transformation reaction. Indeed, the solubility of goethite, schwertmannite, and 2-line ferrihydrite was found to increase in acidic solution, ${ }^{46,47}$ which might accelerate the dissolution of ellipsoidal aggregates, and further led to needle extension caused by a decline of solution $\mathrm{pH}$. These results explicitly indicated that the morphology of schwertmannite was jointly dependent on the solution $\mathrm{pH}, \mathrm{Fe}^{2+}$, and $A$. ferrooxidans. 
2.5. Roles of Solution $\mathrm{OH}^{-}$on the Formation of Schwertmannite. The distribution of $\mathrm{Fe}^{3+}$ species was calculated using Visual MINTEQ. 3.1 software. In the $\mathrm{pH}$ range of $2-3, \mathrm{Fe}$ was mainly existed in the forms of $\mathrm{FeSO}_{4}{ }^{+}$ and $\mathrm{Fe}\left(\mathrm{SO}_{4}\right)_{2}^{-}$, meanwhile, a minor portion of $\mathrm{Fe}^{3+}$ existed as $\mathrm{FeOH}^{2+}$ and $\mathrm{Fe}(\mathrm{OH})_{2}{ }^{+}$complexes (Figure S6). However, the content of hydroxyl complexes was scarcely observed when the $\mathrm{pH}$ was below 2.0. As stated previously, the mineral formed at $3 \mathrm{~h}$ contained $67.6 \%$ of ferrihydrite, a precursor of schwertmannite (Table S1), which corresponded to the solution environment with $\mathrm{pH} 2.8$ (Figure 2a). Therefore, it was speculated that the content of hydroxyl complexes was likely to strongly associate with the formation of schwertmannite. Furthermore, the ferron assay showed that the concentration of $\mathrm{Fe}(\mathrm{b})$ gradually decreased and nearly disappeared after $12 \mathrm{~h}$ (Figure 1d). The conversion from $\mathrm{Fe}(\mathrm{a})$ to $\mathrm{Fe}(\mathrm{b})$ involved two main bridge transformation mechanisms, namely olation and oxolation. ${ }^{48}$ Olation referred to the replacement of aquo-ligands by hydroxo-ligands to form bridging $\mathrm{OH}^{-}$according to Reaction 3 .

$$
\begin{aligned}
& \mathrm{Fe}^{\mathrm{III}}-\mathrm{OH}+\mathrm{Fe}^{\mathrm{III}}-\mathrm{OH}_{2} \\
& \quad \rightarrow \mathrm{Fe}^{\mathrm{III}}-\mathrm{OH}-\mathrm{Fe}^{\mathrm{III}}+\mathrm{H}_{2} \mathrm{O}
\end{aligned}
$$

Oxolation entailed $\mathrm{OH}^{-}$nucleophilic substitution with adjacent $\mathrm{Fe}^{3+}$ to form bridging $\mathrm{O}^{2-}$ according to Reaction 4 .

$$
\begin{aligned}
& \mathrm{Fe}^{\mathrm{III}}-\mathrm{OH}+\mathrm{Fe}^{\mathrm{III}}-\mathrm{OH} \\
& \quad \rightarrow \mathrm{Fe}^{\mathrm{III}}-\mathrm{O}-\mathrm{Fe}^{\mathrm{III}}+\mathrm{H}_{2} \mathrm{O}
\end{aligned}
$$

For the hydrolytic polymerization reactions, the $\mathrm{OH}^{-}$group was essential to promote bridge formation. ${ }^{40}$ In addition, it tended to consume $\mathrm{OH}^{-}$to form bridge groups and simultaneously release water molecules as more closely interconnected bonding networks progressively formed. ${ }^{40,49,50}$

To better understand the effects of solution $\mathrm{pH}$ on the formation process of schwertmannite, four treatments were performed, in which solution $\mathrm{pH}$ was set as initial 2.2 and 2.5, and constant $\mathrm{pH} 2.2$ and 2.5 during the reaction process. As shown in Figure 5a, the $\mathrm{pH}$ in the treatment with initial $\mathrm{pH} 2.2$ and initial $\mathrm{pH} 2.5$ were decreased to approximately 2.0 after 72 $\mathrm{h}$, while it remained stable in constant $\mathrm{pH} 2.2$ and constant $\mathrm{pH}$ 2.5 groups. Figure $5 \mathrm{~b}$ showed that the oxidation efficiency of $\mathrm{Fe}^{2+}$ sharply increased during first $36 \mathrm{~h}$ and reached nearly $100 \%$ after $48 \mathrm{~h}$ in all treatments, implying that the solution $\mathrm{pH}$ had little influence on the rate of bio-oxidation of $\mathrm{Fe}^{2+}$. A similar phenomenon was also observed by Liao et al. during the biological preparation of schwertmannite under different $\mathrm{pH}$ conditions. ${ }^{20}$ The $\mathrm{Fe}$ precipitation efficiency in the treatments with initial $\mathrm{pH} 2.2$, initial $\mathrm{pH} 2.5$, and constant $\mathrm{pH} 2.2$ gradually increased to $21.9,31.5$, and $66.2 \%$ after $72 \mathrm{~h}$, respectively (Figure 5c). However, the $\mathrm{Fe}$ precipitation efficiency in the treatment with constant $\mathrm{pH} 2.5$ was rapidly increased to $91.3 \%$ within $36 \mathrm{~h}$, then slightly reached $96 \%$ after $72 \mathrm{~h}$. These results clearly illustrated that the addition of $\mathrm{OH}^{-}$ during the formation of biogenic schwertmannite greatly enhanced the yield of the mineral. Hence, approximately $30 \%$ of $\mathrm{Fe}$ precipitation efficiency in the treatments without the addition of any $\mathrm{OH}^{-}$during schwertmannite formation should be attributed to the insufficient hydroxyl complexes or the restriction of transformation from $\mathrm{Fe}(\mathrm{a})$ to $\mathrm{Fe}(\mathrm{b})$ caused by the successive decline of solution $\mathrm{pH}$. Further studies were needed to identify the $\mathrm{Fe}$ species present in the nucleation

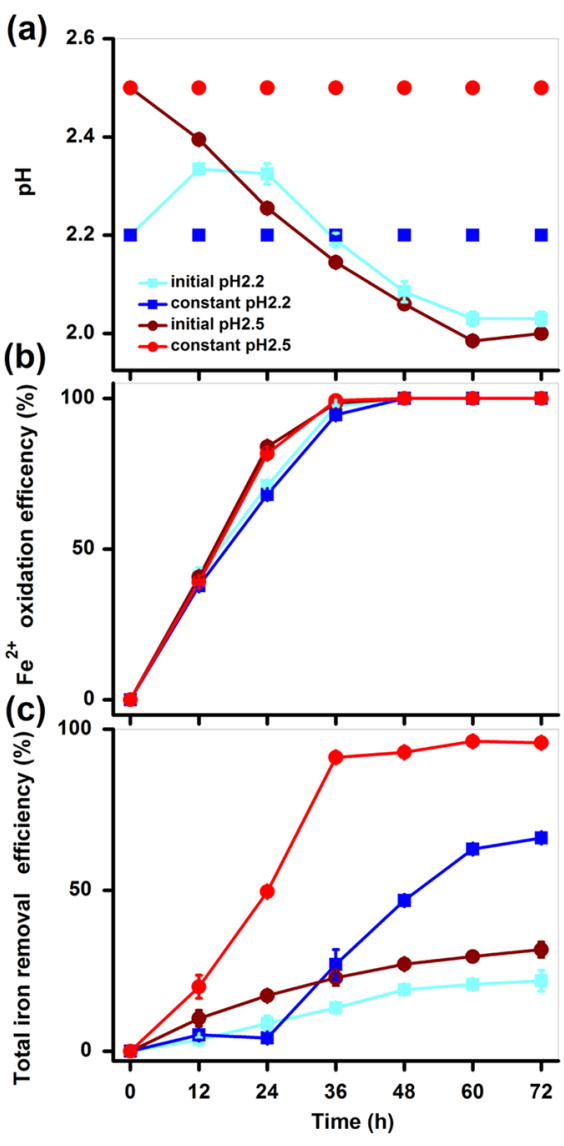

Figure 5. Variation of $\mathrm{pH}$ values (a), ferrous ion oxidation efficiency (b), and total iron removal efficiency (c) during the formation of schwertmannite driven by $A$. ferrooxidans in simulated AMD with or without $\mathrm{pH}$ regulation $\left(80 \mathrm{mM} \mathrm{FeSO}_{4} ;\right.$ A. ferrooxidans density: $6 \times$ $10^{7}$ cell $\mathrm{mL}^{-1}$ ). The experiments set the initial solution $\mathrm{pH}$ to 2.2 and 2.5 without further adjustment, labeled as initial $\mathrm{pH} 2.2$ and initial $\mathrm{pH}$ 2.5 , respectively. Correspondingly, contrast experiments maintained the solution $\mathrm{pH}$ of 2.2 and 2.5 throughout the trial, labeled as constant $\mathrm{pH} 2.2$ and constant $\mathrm{pH} 2.5$, respectively.

stages of schwertmannite at the molecular scale to better understand its formation mechanisms.

\section{CONCLUSIONS}

The formation process of biogenic schwertmannite was tracked by AFM and SEM analyses. Crystallites with simultaneous nonaggregative to aggregative behavior were firstly observed in the initial stage (Step I), which were formed via a successive polymerization reaction. Then the crystallite particles were further gathered together to form ellipsoidal aggregates (Step II) identified as ferrihydrite and schwertmannite. Finally, needles began to grow on the surface of ellipsoidal aggregates (Step III) owing to the phase transformation of ferrihydrite or schwertmannite to lepidocrocite and goethite driven by $\mathrm{Fe}^{2+}$ catalysis. In addition, A. ferrooxidans could also accelerate this process. Solution $\mathrm{pH}$ was a key factor determining the precipitation efficiency of Fe. Maintaining a constant $\mathrm{pH}$ by adding $\mathrm{OH}^{-}$could drastically improve the Fe precipitation efficiency to $96 \%$ from about $30 \%$ without providing $\mathrm{OH}^{-}$ during biological formation of schwertmannite within $72 \mathrm{~h}$. It was concluded that solution chemistry during biological preparation of schwertmannite was, to a great extent, responsible for the morphology and phase transformation of 
the biogenic mineral. The findings were conducive to seeking strategies to effectively treat AMD or obtain lots of functional environmental materials in light of the biomineralization approach.

\section{MATERIALS AND METHODS}

4.1. Preparation of $A$. ferrooxidans Resting Cell Suspension. A. ferrooxidans LX5 (CGMCC No. 0727) was obtained from China General Microbiological Collection Center (CGMCC) and cultured in sterile $9 \mathrm{~K}$ medium as described by Silverman and Lundgren. ${ }^{25}$ The composition of the $9 \mathrm{~K}$ medium is as follows: $44.3 \mathrm{~g}$ of $\mathrm{FeSO}_{4}, 3.0 \mathrm{~g}$ of $\left(\mathrm{NH}_{4}\right)_{2} \mathrm{SO}_{4}, 0.5 \mathrm{~g}$ of $\mathrm{K}_{2} \mathrm{HPO}_{4}, 0.5 \mathrm{~g}$ of $\mathrm{MgSO}_{4} \cdot 7 \mathrm{H}_{2} \mathrm{O}, 0.1 \mathrm{~g}$ of $\mathrm{KCl}$, and $0.01 \mathrm{~g}$ of $\mathrm{Ca}\left(\mathrm{NO}_{3}\right)_{2}$ in $1 \mathrm{~L}$ of deionized water, and the solution $\mathrm{pH}$ was adjusted to 2.5 with $\mathrm{H}_{2} \mathrm{SO}_{4}(50 \%, \mathrm{v} / \mathrm{v})$. A. ferrooxidans was incubated in $500 \mathrm{~mL}$ Erlenmeyer flasks, each containing $250 \mathrm{~mL}$ of $9 \mathrm{~K}$ medium and $10 \%(\mathrm{v} / \mathrm{v})$ inoculum at $28{ }^{\circ} \mathrm{C}$ and $180 \mathrm{rpm}$. A. ferrooxidans resting cells were prepared according to previous methods. ${ }^{26}$ Briefly, A. ferrooxidans at the end of the exponential growth phase (after cultivation for three days) was directly filtered through Whatman No. 4 filter paper to remove precipitates, and then the bacterial cells were collected after centrifuging the filtrate at $10000 \mathrm{~g}$ for $10 \mathrm{~min}$ at $4{ }^{\circ} \mathrm{C}$. The resultant cells were washed three times with $\mathrm{H}_{2} \mathrm{SO}_{4}$ solutions $(\mathrm{pH}=1.5)$, and then resuspended in dilute $\mathrm{H}_{2} \mathrm{SO}_{4}$ solutions $(\mathrm{pH}=2.5)$. After this, the bacterial density was subjected to measurement according to the double-layer plate method. ${ }^{26,27}$

4.2. Biological Synthesis of Schwertmannite. The preparation of schwertmannite was conducted in $500 \mathrm{~mL}$ Erlenmeyer flasks. Briefly, $80 \mathrm{mM} \mathrm{FeSO}_{4}$ solution $(250 \mathrm{~mL})$ was inoculated with $A$. ferrooxidans resting cell $\left(6 \times 10^{7}\right.$ cells $\mathrm{mL}^{-1}$ ) and co-cultured for 5 days at an initial $\mathrm{pH}$ of 2.5 and $180 \mathrm{rpm}\left(28{ }^{\circ} \mathrm{C}\right) .^{28,29}$ At a given time interval, $2 \mathrm{~mL}$ of suspension was withdrawn and determined for $\mathrm{pH}, \mathrm{Fe}^{2+}$, total $\mathrm{Fe}$, and $\mathrm{SO}_{4}{ }^{2-}$ after filtering through a $0.45 \mu \mathrm{m}$ membrane. The resultant precipitate was collected by vacuum filtration and then washed three times with $\mathrm{H}_{2} \mathrm{SO}_{4}$ solution $(\mathrm{pH}=2.0)$ and deionized water, respectively. Finally, the precipitate was freeze-dried for further determination.

In addition, the effect of initial solution $\mathrm{pH}$ on the mineral yield was also investigated by setting up four experimental groups. The first group was labeled as initial $\mathrm{pH} 2.2$, in which solution $\mathrm{pH}$ was adjusted to 2.2 and no longer controlled during the reaction process. The second group was labeled as constant $\mathrm{pH} 2.2$, in which solution $\mathrm{pH}$ was maintained at 2.2 by adding $\mathrm{H}_{2} \mathrm{SO}_{4}(10 \%, \mathrm{v} / \mathrm{v})$ or $\mathrm{NaOH}(5 \mathrm{M})$ every $3 \mathrm{~h}$. The other two groups were initial $\mathrm{pH} 2.5$ and constant $\mathrm{pH} 2.5$, respectively.

4.3. Effect of $\mathrm{Fe}^{2+}, A$. ferrooxidans, and $\mathrm{pH}$ on Schwertmannite Morphology. The mineral sample formed at $9 \mathrm{~h}$ were used to investigate the effect of $\mathrm{Fe}^{2+}, A$. ferrooxidans, and $\mathrm{pH}$ on the morphology of schwertmannite during the biological synthesis process. The pristine mineral $\left(0.14 \mathrm{~g} \mathrm{~L}^{-1}\right)$ was added to five different solutions: (1) $\mathrm{FeSO}_{4}$ solution (30 mM, pH = 2.6), (2) inactive A. ferrooxidans suspension $(\mathrm{pH}=2.6),(3) \mathrm{FeSO}_{4}$ solution $(30 \mathrm{mM}, \mathrm{pH}=$ 2.6) containing inactive A. ferrooxidans suspension, (4) aqueous solution with $\mathrm{pH} 2.6$, and (5) aqueous solution with $\mathrm{pH}$ 2.0. The resultant mixture solution with a total reaction volume of $250 \mathrm{~mL}$ was subjected to further reaction for $108 \mathrm{~h}$. The parameters during the reaction process and procedures for mineral collection were consistent with those described above.

4.4. Analytical Methods. The morphology of the newlyformed mineral during the initial $3 \mathrm{~h}$ reaction in the biological synthesis system was observed by atomic force microscopy (AFM, MultiMode 8; Bruker, Billerica MA). The suspension $(5 \mu \mathrm{L})$ was firstly dropped on a clean quartz slide, air dried for $12 \mathrm{~h}$, and then was observed in air-contact mode. The data were analyzed using NanoScope Analysis software. The morphology of minerals collected at different times was observed by scanning electron microscopy (SEM, Hitachi, Japan) and transmission electron microscopy (TEM, JEOL2011, Tokyo Japan). High-resolution TEM (HRTEM) images were obtained on a JEOL 3000 operated at $300 \mathrm{kV}$ and analyzed using Digital Micrograph software. The mineral phase was determined by X-ray powder diffraction (XRD, MiniFlex II, Japan) using $\mathrm{Cu} \mathrm{K} \alpha$ radiation $(50 \mathrm{kV}, 15 \mathrm{~mA})$. Mössbauer spectra were recorded at $77 \mathrm{~K}$ using a conventional spectrometer (Wissel MS-500, Germany) in transmission mode. A Janis cryostat was used to cool the samples, and ${ }^{57} \mathrm{Co}$ in an $\mathrm{Rh}$ matrix with activity of $25 \mathrm{~m} \mathrm{Ci}$ was used as the source. The velocity calibration was done with an $\alpha$-Fe absorber at room temperature, and spectra were interpreted using Recoil software and the Voigt-based fitting (VBF) method.

Solution $\mathrm{pH}$ was determined using a PHS-3C $\mathrm{pH}$ meter. Turbidity was monitored on a Hach TL2300 turbidity meter. $\mathrm{Fe}^{2+}$ and total $\mathrm{Fe}$ concentrations were analyzed via the 1,10phenanthroline colorimetric method with an UV-2202pcs ultraviolet visible (UV) spectrophotometer. ${ }^{13,30}$ The concentration of $\mathrm{SO}_{4}{ }^{2-}$ was determined by ion chromatography (Dionex ICS-1100). ${ }^{31}$ The distribution of $\mathrm{Fe}^{3+}$ species [monomer-Fe(a), polymer-Fe(b) and precipitate-Fe(c)] was investigated by the ferron (8-hydroxy-7-iodo-5-quinoline sulfonic acid) reaction. ${ }^{21,32,33} \mathrm{Fe}(\mathrm{a})$ and $\mathrm{Fe}(\mathrm{b})$ were distinguished by different complex times, and $\mathrm{Fe}(\mathrm{c})$ was obtained by subtracting $\mathrm{Fe}(\mathrm{a})$ and $\mathrm{Fe}(\mathrm{b})$ from the total $\mathrm{Fe}$ concentration. In order to eliminate the influence of $\mathrm{Fe}^{2+}$ reacting with the ferron reagent, the linear regression fitting between the $\mathrm{Fe}^{2+}$ concentration and absorbance $(600 \mathrm{~nm})$ was estimated (Figure $\mathrm{S} 1)$. Thus, the absorbance intensity of the corresponding $\mathrm{Fe}^{3+}$ ferron complex was obtained after subtracting the absorbance values of the $\mathrm{Fe}^{2+}$-ferron complex.

4.5. Calculation Approach for $\mathrm{Fe}^{3+}$ Speciation. The distribution of $\mathrm{Fe}^{3+}$ ions at different $\mathrm{pH}$ values was calculated using Visual MINTEQ. 3.1 software. The concentrations of $\mathrm{SO}_{4}{ }^{2-}$ and $\mathrm{Fe}^{3+}$ ions were set as $96.3 / 91.2$ and 2.6/57.9 mM, respectively, which corresponded to maximum/minimum values of $\mathrm{SO}_{4}{ }^{2-} / \mathrm{Fe}^{3+}$ during the formation of $A$. ferrooxidansdriven schwertmannite.

\section{ASSOCIATED CONTENT}

\section{Supporting Information}

The Supporting Information is available free of charge at https://pubs.acs.org/doi/10.1021/acsomega.0c05606.

Mössbauer spectral fitting parameters collected at $77 \mathrm{~K}$ for 3 and $120 \mathrm{~h}$ samples (Table S1); linear regression plots of absorbance intensity for the reaction of $\mathrm{Fe}^{2+}$ with ferron (Figure S1); AFM, SEM, and TEM of schwertmannite formed by A. ferrooxidans in simulated acid mine drainage (Figures S2, S3, and S4); HRTEM images of schwertmannite bulges on the surface of 
ellipsoidal aggregates at $36 \mathrm{~h}$ (Figure S5); speciation of $\mathrm{Fe}^{3+}$ as a function of solution $\mathrm{pH}$ (Figure S6); TEM of an ultrathin section of $A$. ferrooxidans showing the magnetosomes (Figure S7) (PDF)

\section{AUTHOR INFORMATION}

\section{Corresponding Author}

Lixiang Zhou - Department of Environmental Engineering, College of Resources and Environmental Science, Nanjing Agricultural University, Nanjing 210095, P. R. China; ○ orcid.org/0000-0002-9978-1163; Email: lxzhou@ njau.edu.cn

\section{Authors}

Kun Feng - Department of Environmental Engineering, College of Resources and Environmental Science, Nanjing Agricultural University, Nanjing 210095, P. R. China Xiaomeng Wang - Department of Environmental Engineering, College of Resources and Environmental Science, Nanjing Agricultural University, Nanjing 210095, P. R. China

Bo Zhou - Department of Environmental Engineering, College of Resources and Environmental Science, Nanjing Agricultural University, Nanjing 210095, P. R. China

Min Xu - Department of Environmental Engineering, College of Resources and Environmental Science, Nanjing Agricultural University, Nanjing 210095, P. R. China

Jianru Liang - Department of Environmental Engineering, College of Resources and Environmental Science, Nanjing Agricultural University, Nanjing 210095, P. R. China

Complete contact information is available at:

https://pubs.acs.org/10.1021/acsomega.0c05606

\section{Notes}

The authors declare no competing financial interest.

\section{ACKNOWLEDGMENTS}

This research was financially supported by the National Natural Science Foundation of China (21637003 and 41977338) and the National Key R\&D Program of China (2020YFC1808003).

\section{REFERENCES}

(1) Hockridge, J. G.; Jones, F.; Loan, M.; Richmond, W. R. An electron microscopy study of the crystal growth of schwertmannite needles through oriented aggregation of goethite nanocrystals. J. Cryst. Growth 2009, 311, 3876-3882.

(2) Liu, F.; Zhou, J.; Zhang, S.; Liu, L.; Zhou, L.; Fan, W. Schwertmannite synthesis through ferrous ion chemical oxidation under different $\mathrm{H}_{2} \mathrm{O}_{2}$ supply rates and its removal efficiency for arsenic from contaminated groundwater. PLoS One 2015, 10, No. e0138891.

(3) Wang, X.; Gu, C.; Feng, X.; Zhu, M. Sulfate local coordination environment in schwertmannite. Environ. Sci. Technol. 2015, 49, 10440-10448.

(4) Yuan, C.; Sleighter, R. L.; Weavers, L. K.; Hatcher, P. G.; Chin, Y. P. Fast photomineralization of dissolved organic matter in acid mine drainage impacted waters. Environ. Sci. Technol. 2019, 53, 62736281.

(5) Schoepfer, V. A.; Burton, E. D.; Johnston, S. G. Contrasting effects of phosphate on the rapid transformation of schwertmannite to $\mathrm{Fe}$ (III) (oxy)hydroxides at near-neutral pH. Geoderma 2019, 340, 115-123.

(6) Zhang, Z.; Guo, G.; Li, X.; Zhao, Q.; Bi, X.; Wu, K.; Chen, H. Effects of hydrogen-peroxide supply rate on schwertmannite micro- structure and chromium(VI) adsorption performance. J. Hazard. Mater. 2019, 367, 520-528.

(7) Song, Y.; Liu, Y.; Wang, H. Comparison of the biological and chemical synthesis of schwertmannite at a consistent $\mathrm{Fe}^{2+}$ oxidation efficiency and the effect of extracellular polymeric substances of Acidithiobacillus ferrooxidans on biomineralization. Materials 2018, 11, No. 1739.

(8) Eskandarpour, A.; Sassa, K.; Bando, Y.; Okido, M.; Asai, S. Magnetic removal of phosphate from wastewater using schwertmannite. Mater. Trans. 2006, 47, 1832-1837.

(9) Boukemara, L.; Boukhalfa, C.; Azzouz, S.; Reinert, L.; Duclaux, L.; Amrane, A.; Szymczyk, A. Characterization of phosphorus interaction with sediments affected by acid mine drainage - relation with the sediment composition. Int. J. Sediment. Res. 2017, 32, 481486.

(10) Collins, R. N.; Jones, A. M.; Waite, T. D. Schwertmannite stability in acidified coastal environments. Geochim. Cosmochim. Acta 2010, 74, 482-496.

(11) Liu, F.; Zhou, J.; Zhou, L.; Zhang, S.; Liu, L.; Wang, M. Effect of neutralized solid waste generated in lime neutralization on the ferrous ion bio-oxidation process during acid mine drainage treatment. J. Hazard. Mater. 2015, 299, 404-411.

(12) Kirby, C. S.; Thomas, H. M.; Southam, G.; Donald, R. Relative contributions of abiotic and biological factors in $\mathrm{Fe}(\mathrm{II})$ oxidation in mine drainage. Appl. Geochemistry 1999, 14, 511-530.

(13) Liu, H.; Lu, X.; Zhang, L.; Xiang, W.; Zhu, X.; Li, J.; Wang, X.; Lu, J.; Wang, R. Collaborative effects of Acidithiobacillus ferrooxidans and ferrous ions on the oxidation of chalcopyrite. Chem. Geol. 2018, 493, 109-120.

(14) Bevilaqua, D.; Leite, A. L. L. C.; Garcia, O.; Tuovinen, O. H. Oxidation of chalcopyrite by Acidithiobacillus ferrooxidans and Acidithiobacillus thiooxidans in shake flasks. Process Biochem. 2002, $38,587-592$.

(15) Tu, Z.; Guo, C.; Zhang, T.; Lu, G.; Wan, J.; Liao, C.; Dang, Z. Investigation of intermediate sulfur species during pyrite oxidation in the presence and absence of Acidithiobacillus ferrooxidans. Hydrometallurgy 2017, 167, 58-65.

(16) Zhang, S.; Yan, L.; Xing, W.; Chen, P.; Zhang, Y.; Wang, W. Acidithiobacillus ferrooxidans and its potential application. Extremophiles 2018, 22, 563-579.

(17) Song, Y.; Wang, M.; Liang, J.; Zhou, L. High-rate precipitation of iron as jarosite by using a combination process of electrolytic reduction and biological oxidation. Hydrometallurgy 2014, 143, 2327.

(18) Jensen, A. B.; Webb, C. Ferrous sulphate oxidation using Thiobacillus ferrooxidans: A Review. Process Biochem. 1995, 30, 225236

(19) Temple, K. L.; Colmer, A. R. The Autotrophic Oixdation of Iron by a New Bacterium: Thiobacillus ferrooxidans. J. Bacteriol. 1951, $62,605-611$.

(20) Liao, Y.; Zhou, L.; Liang, J.; Xiong, H. Biosynthesis of schwertmannite by Acidithiobacillus ferrooxidans cell suspensions under different pH condition. Mater. Sci. Eng. C 2009, 29, 211-215.

(21) Zhu, M.; Legg, B.; Zhang, H.; Gilbert, B.; Ren, Y.; Banfield, J. F.; Waychunas, G. A. Early stage formation of iron oxyhydroxides during neutralization of simulated acid mine drainage solutions. Environ. Sci. Technol. 2012, 46, 8140-8147.

(22) Fortin, D.; Davis, B.; Southam, G.; Beveridge, T. J. Biogeochemical phenomena induced by bacteria within sulfidic mine tailings. J. Ind. Microbiol. 1995, 14, 178-185.

(23) Ferris, F. G.; Hallbeck, L.; Kennedy, C. B.; Pedersen, K. Geochemistry of acidic pio tinto headwaters and role of bacteria in solid phase metal partitioning. Chem. Geol. 2004, 212, 291-300.

(24) Hedrich, S.; Lünsdorf, H.; Kleeberg, R.; Heide, G.; Seifert, J.; Schlömann, M. Schwertmannite formation adjacent to bacterial cells in a mine water treatment plant and in pure cultures of Ferrovum myxofaciens. Environ. Sci. Technol. 2011, 45, 7685-7692.

(25) Silverman, M. P.; Lundgren, D. G. Studies on the chemoautotrophic iron bacterium Ferrobacillus ferrooxidans I. an improved 
medium and a harvesting procedure for securing high cell yields. J. Bacteriol. 1959, 77, 642-647.

(26) Bai, S.; Xu, Z.; Wang, M.; Liao, Y.; Liang, J.; Zheng, C.; Zhou, L. Both initial concentrations of $\mathrm{Fe}$ (II) and monovalent cations jointly determine the formation of biogenic iron hydroxysulfate precipitates in acidic sulfate-rich environments. Mater. Sci. Eng. C 2012, 32, 23232329.

(27) Jin, D.; Liu, L.; Zheng, G.; Liang, J.; Zhou, L. A rapid method to quantify the biomass of viable Acidithiobacillus ferrooxidans in ironbased bioleaching matrix of sewage sludge. Biochem. Eng. J. 2019, 152, No. 107360.

(28) Song, Y.; Yang, L.; Wang, H.; Sun, X.; Bai, S.; Wang, N.; Liang, J.; Zhou, L. The coupling reaction of $\mathrm{Fe}^{2+}$ bio-oxidation and resulting $\mathrm{Fe}^{3+}$ hydrolysis drastically improve the formation of iron hydroxysulfate minerals in AMD. Environ. Technol. 2019, 1-26.

(29) Wang, N.; Fang, D.; Zheng, G.; Liang, J.; Zhou, L. A novel approach coupling ferrous iron bio-oxidation and ferric iron chemoreduction to promote biomineralization in simulated acidic mine drainage. RSC Adv. 2019, 9, 5083-5090.

(30) Harvey, A. E.; Smart, J. A.; Amis, E. S. Simultaneous spectrophotometric determination of iron(II) and total iron with 1,10-phenanthroline. Anal. Chem. 1955, 27, 26-29.

(31) Wang, X.; Jiang, H.; Fang, D.; Liang, J.; Zhou, L. A novel approach to rapidly purify acid mine drainage through chemically forming schwertmannite followed by lime neutralization. Water Res. 2019, 151, 515-522.

(32) Wei, J.; Gao, B.; Yue, Q.; Wang, Y.; Li, W.; Zhu, X. Comparison of coagulation behavior and floc structure characteristic of different polyferric-cationic polymer dual-coagulants in humic acid solution. Water Res. 2009, 43, 724-732.

(33) Cao, B.; Gao, B.; Wang, M.; Sun, X.; Wang, J. Floc properties of polyaluminum ferric chloride in water treatment: the effect of $\mathrm{Al} / \mathrm{Fe}$ molar ratio and basicity. J. Colloid Interface Sci. 2015, 458, 247-254.

(34) Scheck, J.; Wu, B.; Drechsler, M.; Rosenberg, R.; Van Driessche, A. E. S.; Stawski, T. M.; Gebauer, D. The molecular mechanism of iron(III) oxide nucleation. J. Phys. Chem. Lett. 2016, 7, 3123-3130.

(35) Zhu, M.; Frandsen, C.; Wallace, A. F.; Legg, B.; Khalid, S.; Zhang, H.; Mørup, S.; Banfield, J. F.; Waychunas, G. A. Precipitation pathways for ferrihydrite formation in acidic solutions. Geochim. Cosmochim. Acta 2016, 172, 247-264.

(36) Long, G. J.; Stevens, J. G. A study of the initially-formed hydrolysis species and intermediate polymers and their role in determining the product iron oxides formed in the weathering of iron. In Industrial Applications of the Mössbauer Effect; Plenum Press, 1987; pp 565-583.

(37) Michot, L. J.; Montargès-Pelletier, E.; Lartiges, B. S.; d'Espinose de la Caillerie, J.-B.; Briois, V. Formation mechanism of the Ga-13 keggin ion: a combined EXAFS and NMR study. J. Am. Chem. Soc. 2000, 122, 6048-6056.

(38) Lei, G.; Ma, J.; Guan, X.; Song, A.; Cui, Y. Effect of basicity on coagulation performance of polyferric chloride applied in eutrophicated raw water. Desalination 2009, 247, 518-529.

(39) Hiemstra, T. Formation, stability, and solubility of metal oxide nanoparticles: surface entropy, enthalpy, and free Energy of ferrihydrite. Geochim. Cosmochim. Acta 2015, 158, 179-198.

(40) Sheng, A.; Liu, J.; Li, X.; Qafoku, O.; Collins, R. N.; Jones, A. M.; Pearce, C. I.; Wang, C.; Ni, J.; Lu, A.; Rosso, K. M. Labile Fe(III) from sorbed $\mathrm{Fe}(\mathrm{II})$ oxidation is the key intermediate in $\mathrm{Fe}(\mathrm{II})$ catalyzed ferrihydrite transformation. Geochim. Cosmochim. Acta 2020, 272, $105-120$.

(41) Poth, P. Corrosion Books: The iRon Oxides - Structure, Properties, Reactions, Occurences And Uses. By: R. M. Cornell, U. Schwertmann. Mater. Corros. 2004, 55, 704.

(42) Yee, N.; Shaw, S.; Benning, L. G.; Nguyen, T. H. The rate of ferrihydrite transformation to goethite via the $\mathrm{Fe}(\mathrm{II})$ pathway. Am. Mineral. 2006, 91, 92-96.

(43) Jones, A. M.; Collins, R. N.; Rose, J.; Waite, T. D. The effect of silica and natural organic matter on the $\mathrm{Fe}(\mathrm{II})$-catalysed trans- formation and reactivity of $\mathrm{Fe}(\mathrm{III})$ Minerals. Geochim. Cosmochim. Acta 2009, 73, 4409-4422.

(44) Burton, E. D.; Bush, R. T.; Sullivan, L. A.; Mitchell, D. R. G. Schwertmannite transformation to goethite via the $\mathrm{Fe}(\mathrm{II})$ pathway: reaction rates and implications for iron-sulfide formation. Geochim. Cosmochim. Acta 2008, 72, 4551-4564.

(45) Liu, T.; Wang, Y.; Liu, C.; Li, X.; Cheng, K.; Wu, Y.; Fang, L.; Li, F.; Liu, C. Conduction band of hematite can mediate cytochrome reduction by $\mathrm{Fe}(\mathrm{II})$ under dark and anoxic conditions. Environ. Sci. Technol. 2020, 54, 4810-4819.

(46) Regenspurg, S.; Brand, A.; Peiffer, S. Formation and stability of schwertmannite in acidic mining lakes. Geochim. Cosmochim. Acta 2004, 68, 1185-1197.

(47) España, J. S. The behavior of iron and aluminum in acid mine drainage. speciation, mineralogy, and environmental significance. Thermodynamics, Solubility and Environmental Issues; Elsevier, 2007; pp 137-150.

(48) Henry, M.; Jolivet, J. P.; Livage, J. Aqueous chemistry of metal cations: hydrolysis, condensation and complexation. ChemInform 1992, 23, 153-206.

(49) Szytula, A.; Burewicz, A.; Dimitrijevic, Ž.; Kraśnicki, S.; Rzany, H.; Todorovic, J.; Wanic, A.; Wolski, W. Neutron diffraction studies of $\alpha$-FeOOH. Phys. Status Solidi (b) 1968, 26, 429-434.

(50) Oleś, A.; Szytula, A.; Wanic, A. Neutron diffraction Study of $\gamma$ FeOOH. Phys. Status Solidi (b) 1970, 41, 173-177. 